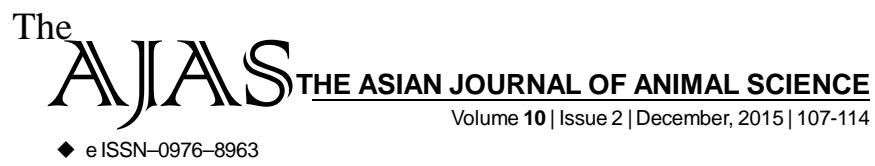

DOI : 10.15740/HAS/TAJAS/10.2/107-114 Visit us | www.researchjournal.co.in $\mathrm{S}$

RESEARCH ARTICLE.

\title{
Effect of bajra flour (Pearl millet) on some quality and sensory attributes of chicken nuggets
}

PARVEEZ AHMAD PARA AND SUBHA GANGULY

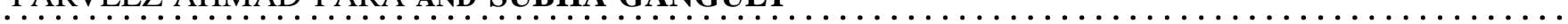

Author for Corresponding -

\section{SUBHA GANGULY}

Department of Veterinary

Microbiology, Arawali Veterinary

College, Bajor,

SIKAR (RAJASTHAN) INDIA

Email: ganguly38@gmail.com

See end of the article for

Coopted authors'
ABSTRACT...... The objective of this study was to develop chicken nuggets with the inclusion of bajra flour (BF). The products were assessed for $\mathrm{pH}$, cooking yield (CY), emulsion stability (ES) and sensory properties. Chicken nuggets were prepared with the addition of 0 per cent, 10 per cent and 20 per cent of BF (bajra flour) over and above the quantity of meat. The cooking yield was significantly $(\mathrm{p}<0.05)$ higher in the nuggets containing BF. The increased $\mathrm{BF}$ level significantly $(\mathrm{p}<0.05)$ increased the $\mathrm{ES}$ however, the $\mathrm{pH}$ of the products increased gradually with level of incorporation and it was significantly higher $(\mathrm{P}<0.05)$ at 20 per cent level of incorporation as compared to control, while as the values at 0 and 10 per cent levels were comparable. The scores for colour and appearance and flavour showed a gradual nonsignificant ( $p>0.05)$ decreasing trend whereas, the texture, juiciness and overall acceptability scores were significantly $(\mathrm{p}<0.05)$ higher at 10 per cent level of incorporation though comparable to control. Hence, chicken nuggets can be made with the addition of BF up to 10 per cent over and above the amount of chicken meat.

KEY WORDS...... Bajra flour, Chicken nuggets, Sensory attributes

HOW TO CITE THIS ARTICLE - Para, Parveez Ahmad and Ganguly, Subha (2015). Effect of bajra flour (Pearl millet) on some quality and sensory attributes of chicken nuggets. Asian J. Animal Sci., 10(2): 107-114.

ARTICLE CHRONICLE - Received : 08.08.2015; Revised : 10.10.2015; Accepted : 23.10.2015 